\title{
Influence of Ageing on Photo- and Thermo-Control of Seed Germination in Grand Rapids Lettuce (Lactuca sativa L.)
}

\author{
Yoshihiro SUZUkI \\ Faculty of Education, Fukushima University, Matsukawa-Machi, Fukushima, 960-12 Japan
}

(Received May 25, 1989)

\begin{abstract}
The reversible photoreaction of $\mathrm{R}$ (Red light) and FR (Far-red light) controlling the seed germination in Grand Rapids lettuce (Lactuca sativa L.) varies markedly not only with germination temperature, but also with the physiological state of seed caused by ageing. The photoreversibility in Grand Rapids lettuce seeds is more evident in the dormant (fresh) and deteriorating (60 and 66 months after harvest) seeds. The reversibility in the non-dormant seeds, however, can be induced again by a prolonged expsoure to FR light or high $\left(40^{\circ} \mathrm{C}\right)$ temperature pretreatment after the onset of imbibition. The velocity and the viability in germination of the seeds exposed to the prolonged FR light or heat-sensitized at $40^{\circ} \mathrm{C}$ for $48 \mathrm{hr}$ maintained for a longer time than in the seeds having no exposure to FR light or heat-sensitization. The photoreversible induction by the prolonged exposure to FR light is due to the secondary photo-dormant stage of the seeds. The photo-reversible induction by a heat-sensitization after the onset of imbibition, on the other hand, is due to the two different physiological states of the seed; a, the secondary thermo-dormant stage caused at $40^{\circ} \mathrm{C}$ for $48 \mathrm{hr}$, and $\mathrm{b}$, the deteriorating stage caused by the thermal injury at $40^{\circ} \mathrm{C}$ for $144 \mathrm{hr}$. Germination induction effects in the heat-sensitized seeds with high temperature pretreatment after the onset of imbibition are greater in $\mathrm{GA}_{3}$ than in $\mathrm{R}$ light.
\end{abstract}

\section{INTRODUCTION}

The germination of light-sensitive seeds is controlled by a reversible photoreaction. ${ }^{1-5)}$ There is, however, considerable variation between different seed stocks, which depends largely on the history of the parent plant, ${ }^{6,7)}$ and the seeds after harvest. $^{8-10)}$ There are only a few precise data on the relationships between the physiological states of seeds caused by ageing and germination temperature under the phytochrome control of seed germination.

The present paper reports the photo- and thermo-control system in lettuce seed germination at various temperatures, using the seeds in different physiological states, that is, dormant, non-dormant and aged ones.

\section{MATERIALS AND METHODS}

Lettuce plants (Lactuca sativa L. Grand Rapids) were grown in the green house of Fukushima University in 1978. Seeds were harvested from the mother plants about 23 days after anthesis. Harvested seeds were air-dried $(5.9-6.8 \%$ water contents in seeds) and kept in paper bags in a wooden box at a controlled temperature $\left(20 \pm 2^{\circ} \mathrm{C}\right)$ until used. 
Fifty seeds were sown on two layers of Töyō No. 3 filter paper moistende with $1 \mathrm{ml}$ distilled water in a $4-\mathrm{cm}$ diameter Petri dish. The dishes were then wrapped in a light-proof paper, which was removed when irradiation was given, $8 \mathrm{hr}$ after the beginning of the dark period.

Heat-sensitization and prolonged FR light irradiation were carried out as follows: fifty non-dormant ( 24 months after harvest) seeds were exposed to $20^{\circ} \mathrm{C}$ for $4 \mathrm{hr}$ dark period after they were sown on two layers of Töyō No. 3 filter paper moistened with $1 \mathrm{ml}$ distilled water in a $4-\mathrm{cm}$ diameter Petri dish, and then were wrapped with a light proof paper. They were exposed to $40^{\circ} \mathrm{C}$ in a moist chamber for various hours, or exposed to FR light at $20^{\circ} \mathrm{C}$ for 48 and $144 \mathrm{hr}$. The light-proof paper was removed from the dish at the time irradiation was given, the solution was changed from distilled water to $\mathrm{GA}_{3} 10^{-3} \mathrm{M}$ solution, or $\mathrm{GA}_{3} 10^{-3} \mathrm{M}$ solution to distilled water, and 0.2 $0.4 \mathrm{ml}$ distilled water was added at $48 \mathrm{hr}$ interval to prevent drying in Petri dish.

$\mathrm{R}(660 \mathrm{~nm})$ and FR $(730 \mathrm{~nm})$ lights were obtained by biological spectrograph, ${ }^{9,10}$ ) and light intensity at the level of seed was adjusted to $3.0 \mathrm{Wm}^{-2}$ for $\mathrm{R}$ and FR lights.

The percent germination was determined $48 \mathrm{hr}$ after sowing or the transferring of the seeds at 20 or $25^{\circ} \mathrm{C}$ after prolonged exposure to $\mathrm{FR}$ light or heat-sensitization, and is expressed as an average of four dishes with a \pm standard error.

\section{RESULTS}

\section{Variability of photoreversible induction by $R$ and $F R$ lights in germination}

Grand Rapids lettuce seed showed phytochrome control of germination both at 15 and $20^{\circ} \mathrm{C}$ when they were sown immediately after seed harvest (Table 1). They, however, did not show any reversibility both at 15 and $20^{\circ} \mathrm{C}$ with 6,12 and 24 months after it, because they germinated more than $94 \%$ in darkness or under 5-min FR light irradiation. They showed completely reversible at $25^{\circ} \mathrm{C}$ with 0 month after harvest. The reversibility, however, began to decrease with 6,12 and 24 months, and increased again with $36,48,60$ and 66 months. At $30^{\circ} \mathrm{C}$, they showed completely reversibility with $6,12,24$ and 36 months after harvest, but their germination rate did not show more than $84 \%$ even by 5 -min exposure to $\mathrm{R}$ light (Table 1 ). Their reversibility, however, did not show at $30^{\circ} \mathrm{C}$ with 0,60 and 66 months after harvest, because they did not germinate by 5 -min exposure to R light at $30^{\circ} \mathrm{C}$.

The 24-month-aged seeds which had become non-photoreversible by 5 -min exposure to $\mathrm{R}$ and $\mathrm{FR}$ lights at $20^{\circ} \mathrm{C}$ can induce again their reversibility by prolonged (48 or $144 \mathrm{hr}$ ) exposure to FR light (Fig. 1). Their reversibility, also can be induced again at the germination temperature of $20^{\circ} \mathrm{C}$ by heat-sensitization at $40^{\circ} \mathrm{C}$ for $24,48,72,96$ and $120 \mathrm{hr}$ after the onset of imbibition (Table 2).

\section{Effects of $R$ light or $G A_{3}$ on germination in the seeds exposed to the prolonged F $R$ light or heat-sensitized}

The seeds irradiated at $20^{\circ} \mathrm{C}$ for 48 or $144 \mathrm{hr}$ with 24,36 and 48 months after harvest germinated $91-98 \%$ respectively at the germination temperature of $20^{\circ} \mathrm{C}$ by the application of $\mathrm{GA}_{3}$ (Fig. 2).

The heat-sensitized seeds kept at $40^{\circ} \mathrm{C}$ for $48 \mathrm{hr}$ with 24 months after harvest germinated $61-62 \%$ at the germination temperature of $20^{\circ} \mathrm{C}$ in darkness or by 5 -min

\footnotetext{
* $\mathrm{GA}_{3}$ : Gibberellic acid $\mathrm{A}_{3}$ are purchased from Wakō Chemicals Co., Japan.
} 
Table 1 Germination of lettuce seeds after exposure to $\mathrm{R}^{*}(5-\mathrm{min})$ and $\mathrm{FR} * *$ (5-min) radiation in sequence.

\begin{tabular}{|c|c|c|c|c|c|c|c|c|c|}
\hline \multirow{2}{*}{$\begin{array}{l}\text { Germination } \\
\text { temperature } \\
\qquad\left({ }^{\circ} \mathrm{C}\right)\end{array}$} & \multirow{2}{*}{$\begin{array}{l}\text { Irradi- } \\
\text { ation*** }\end{array}$} & \multicolumn{8}{|c|}{ Germination following seed storage for indicated months $(\%)$} \\
\hline & & 0 & 6 & 12 & 24 & 36 & 48 & 60 & 66 \\
\hline \multirow{5}{*}{15} & Dark & $82 \pm 2$ & 100 & $98 \pm 1$ & 99 & $98 \pm 1$ & $89 \pm 1$ & $47 \pm 3$ & $33 \pm 2$ \\
\hline & $\mathrm{R}$ & $99 \pm 1$ & 100 & 100 & 100 & $98 \pm 1$ & $99 \pm 1$ & $98 \pm 1$ & 99 \\
\hline & FR & $57 \pm 3$ & $96 \pm 2$ & $95 \pm 2$ & $97 \pm 2$ & $81 \pm 3$ & $58 \pm 3$ & $27 \pm 2$ & $22 \pm 1$ \\
\hline & F-FR & $66 \pm 2$ & 99 & $98 \pm 1$ & $98 \pm 1$ & $84 \pm 3$ & $61 \pm 3$ & $36 \pm 2$ & $35 \pm 1$ \\
\hline & F-FR-R & $97 \pm 3$ & $98 \pm 1$ & 99 & 100 & $98 \pm 2$ & $97 \pm 1$ & 99 & $97 \pm 1$ \\
\hline \multirow{5}{*}{20} & Dark & $47 \pm 3$ & 99 & 100 & 99 & 100 & $92 \pm 2$ & $25 \pm 3$ & $19 \pm 2$ \\
\hline & $\mathrm{R}$ & $96 \pm 2$ & 99 & 100 & 100 & 99 & $98 \pm 1$ & $97 \pm 2$ & 99 \\
\hline & FR & $7 \pm 1$ & $94 \pm 4$ & $97 \pm 1$ & $98 \pm 2$ & $67 \pm 2$ & $49 \pm 3$ & $18 \pm 1$ & $15 \pm 3$ \\
\hline & R-FR & $24 \pm 2$ & 100 & 99 & $97 \pm 1$ & $78 \pm 3$ & $62 \pm 2$ & $39 \pm 3$ & $26 \pm 2$ \\
\hline & R-FR-R & $95 \pm 2$ & $98 \pm 1$ & 100 & 99 & 100 & 100 & 99 & $97 \pm 1$ \\
\hline \multirow{5}{*}{25} & Dark & $6 \pm 1$ & $80 \pm 3$ & $93 \pm 2$ & $88 \pm 2$ & $73 \pm 2$ & $51 \pm 3$ & 0 & 0 \\
\hline & $\mathrm{R}$ & $88 \pm 3$ & 100 & 99 & 99 & 100 & 97 & $93 \pm 2$ & 99 \\
\hline & FR & 1 & $59 \pm 2$ & $78 \pm 3$ & $69 \pm 3$ & $25 \pm 1$ & $18 \pm 2$ & 1 & 1 \\
\hline & R-FR & $8 \pm 1$ & $63 \pm 2$ & $83 \pm 2$ & $74 \pm 3$ & $36 \pm 3$ & $25 \pm 3$ & $5 \pm 1$ & $6 \pm 1$ \\
\hline & R-FR-R & $93 \pm 3$ & 99 & 100 & $98 \pm 2$ & $97 \pm 2$ & $98 \pm 1$ & $92 \pm 1$ & $97 \pm 2$ \\
\hline \multirow{5}{*}{30} & Dark & 0 & 0 & 0 & 0 & 0 & 0 & 0 & 0 \\
\hline & $\mathrm{R}$ & 0 & $71 \pm 3$ & $76 \pm 3$ & $65 \pm 2$ & $47 \pm 4$ & $18 \pm 1$ & 0 & 0 \\
\hline & FR & 0 & 0 & 0 & 0 & 0 & 0 & 0 & 0 \\
\hline & R-FR & 0 & 0 & 0 & 0 & 0 & 0 & 0 & 0 \\
\hline & R-FR-R & 0 & $79 \pm 1$ & $84 \pm 2$ & $78 \pm 3$ & $58 \pm 2$ & $27 \pm 2$ & 0 & 0 \\
\hline
\end{tabular}

* R: Red light.

** FR: Far-red light.

*** Irradiation was given $8 \mathrm{hr}$ after the beginning of dark period.

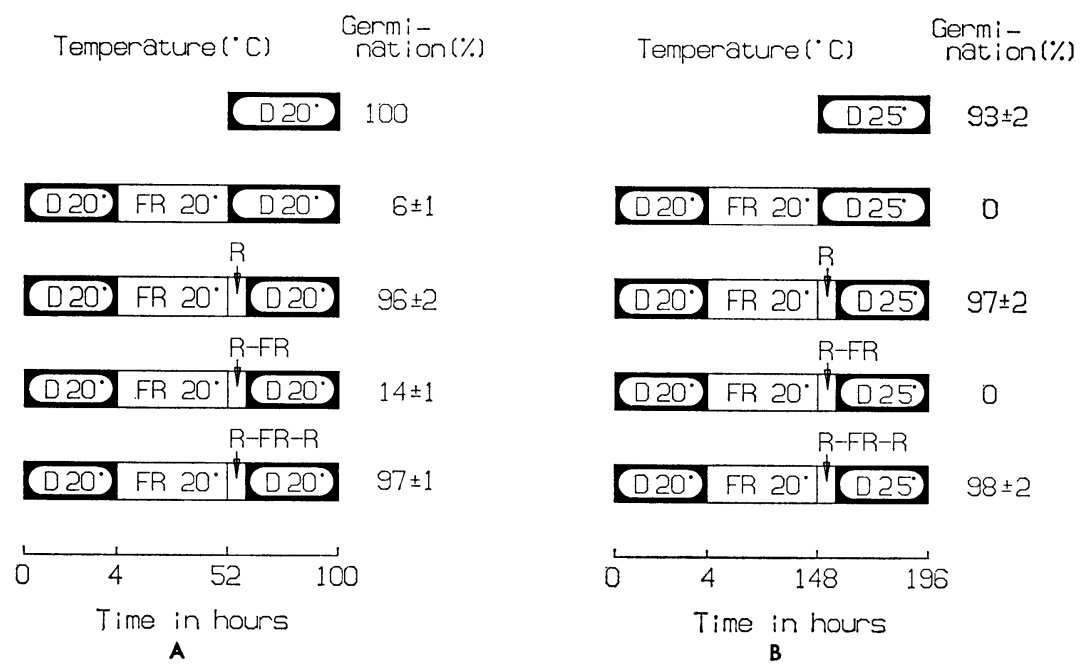

Fig. 1 Germination of the prolonged FR light-irradiated seeds after exposure to $R$ (5-min) and $\mathrm{FR}(5-\mathrm{min})$ radiation in sequence.

A, FR light-irradiation for $48 \mathrm{hr}$; B, FR light-irradiation for $144 \mathrm{hr}$. 
Table 2 Germination of heat $\left(40^{\circ} \mathrm{C}\right)$-sensitive lettuce seeds after exposure to $\mathrm{R}(5$ min) and FR (5-min) radiation.

\begin{tabular}{|c|c|c|c|c|c|c|c|c|}
\hline \multirow{3}{*}{$\begin{array}{l}\text { Germination } \\
\text { temperature } \\
\left({ }^{\circ} \mathrm{C}\right)\end{array}$} & \multirow{3}{*}{ Irradiation $* *$} & \multicolumn{7}{|c|}{ Germination $(\%)$} \\
\hline & & \multicolumn{7}{|c|}{ Heat-sensitization* (hr) } \\
\hline & & 24 & 48 & 72 & 96 & 120 & 144 & 168 \\
\hline \multirow{5}{*}{20} & Dark & $15 \pm 1$ & 0 & 0 & 0 & 0 & 0 & 0 \\
\hline & $\mathrm{R}$ & $94 \pm 2$ & $91 \pm 2$ & $92 \pm 2$ & $93 \pm 2$ & $33 \pm 2$ & $8 \pm 1$ & 1 \\
\hline & FR & $71 \pm 1$ & $9 \pm 1$ & $7 \pm 1$ & 0 & 0 & 0 & 0 \\
\hline & R-FR & $80 \pm 3$ & $14 \pm 2$ & $14 \pm 1$ & $6 \pm 1$ & $5 \pm 1$ & 0 & 0 \\
\hline & R-FR-R & $97 \pm 1$ & $95 \pm 2$ & $93 \pm 2$ & $95 \pm 1$ & $51 \pm 4$ & $9 \pm 2$ & 0 \\
\hline
\end{tabular}

* Heat-sensitization was given to the 24-month-aged seeds $4 \mathrm{hr}$ after the beginning of dark period at $20^{\circ} \mathrm{C}$.

** Irradiation was given just after transferring to $20^{\circ} \mathrm{C}$ of germination temperature from high temperature pretreatment after the onset of imbibition.

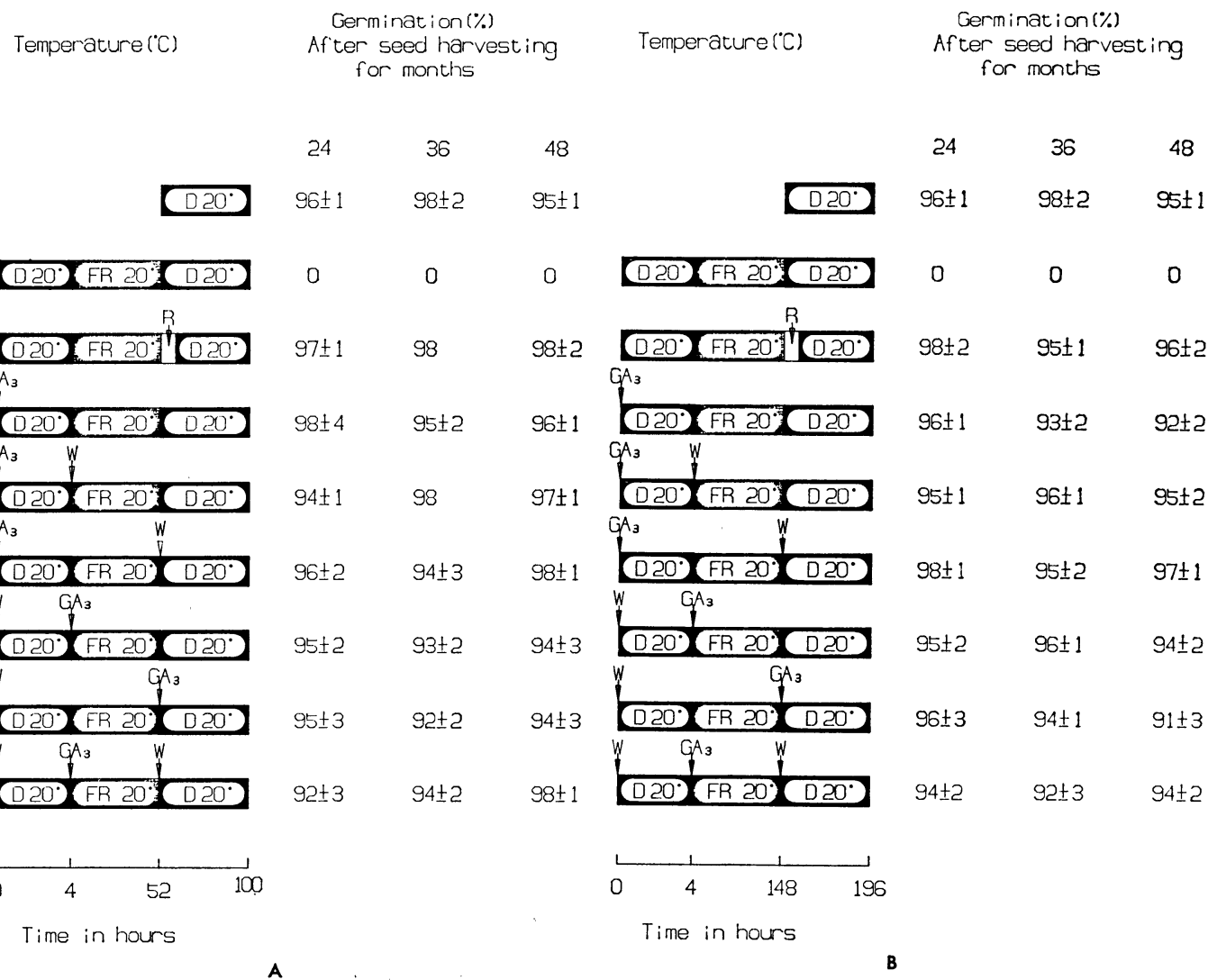

Fig. 2 Effects of $\mathrm{R}$ and $\mathrm{GA}_{3}$ on germination of the prolonged FR light-irradiated seeds.

A, FR light-irradiation for $48 \mathrm{hr}$; B, FR irradiation for $144 \mathrm{hr}$; R, red light; $\mathrm{GA}_{3}$, gibberellic acid $\mathrm{A}_{3} ; \mathrm{W}$, distilled water. 


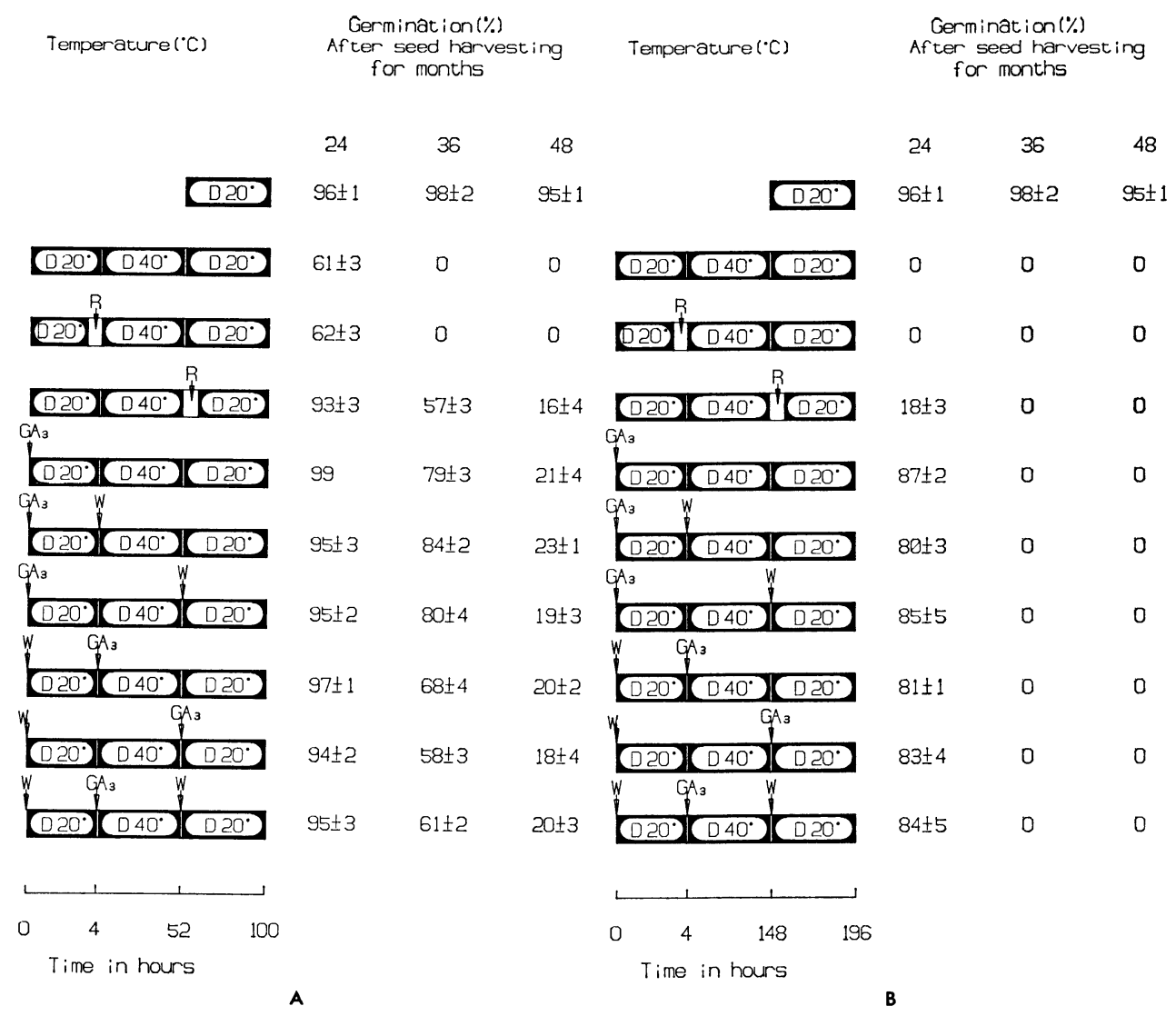

Fig. 3 Effects of $\mathrm{R}$ and $\mathrm{GA}_{3}$ on germination of the heat-sensitized seeds. A, heat-sensitization for $48 \mathrm{hr}$; $\mathrm{B}$, heat-sensitization for $144 \mathrm{hr}$; $\mathrm{R}$, red light; $\mathrm{GA}_{3}$, gibberellic acid $\mathrm{A}_{3} ; \mathrm{W}$, distilled water.

exposure to $\mathrm{R}$ light before heat-sensitization, but they germinated $93 \%$ by 5 -min exposure to $\mathrm{R}$ light after heat-sensitization (Fig. 3-A). The effects of $\mathrm{GA}_{3}$ on their germination, however, showed very high percentage regardless of the application before or after heat-sensitization. The heat-sensitized seeds kept at $40^{\circ} \mathrm{C}$ for $48 \mathrm{hr}$ with 36 and 48 months, on the other hand, did not germinate at all even at the germination temperature of $20^{\circ} \mathrm{C}$ in darkness or by 5 -min exposure to $\mathrm{R}$ light before heat-sensitization (Fig. 3-A). The heat-sensitized ones kept at $40^{\circ} \mathrm{C}$ for $48 \mathrm{hr}$ with 48 months did not germinate more than $23 \%$ by 5 -min exposure to $\mathrm{R}$ light after heat-sensitization or by the application of $\mathrm{GA}_{3}$, though the heat-sensitized ones kept at $40^{\circ} \mathrm{C}$ for $48 \mathrm{hr}$ with 36 months germinated $57-84 \%$ respectively (Fig. 3-A).

The heat-sensitized seeds kept at $40^{\circ} \mathrm{C}$ for $144 \mathrm{hr}$ with 24 months after harvest germinated $80-87 \%$ respectively by the application of $\mathrm{GA}_{3}$ before or after heat-sensitization, though they did not germinate at all at $20^{\circ} \mathrm{C}$ in darkness or germinated only $18 \%$ by 5 -min exposure to $\mathrm{R}$ light after heat-sensitization (Fig. 3-B). The similar heat-sensitized seeds with 36 and 48 months, on the other hand, did not germinate 


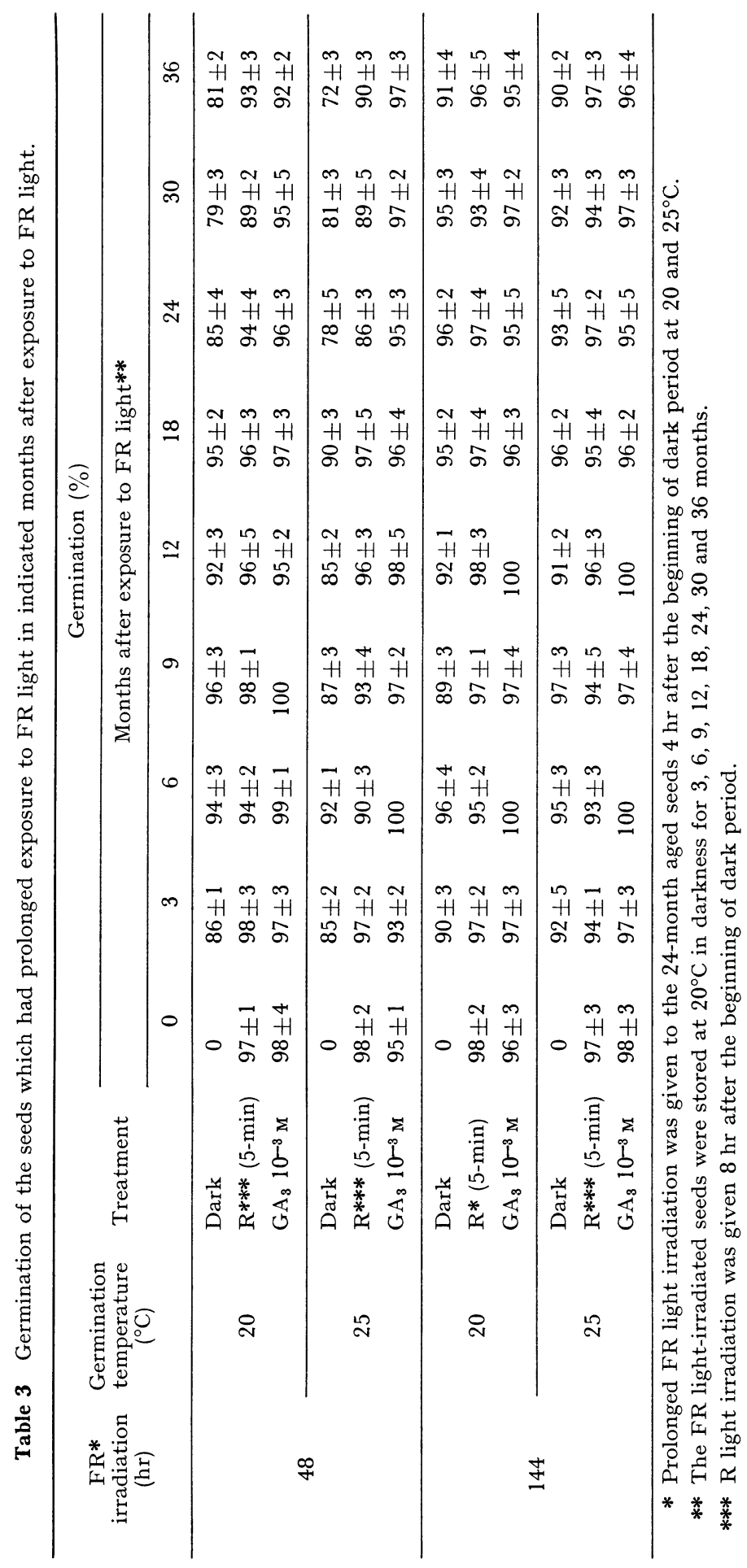




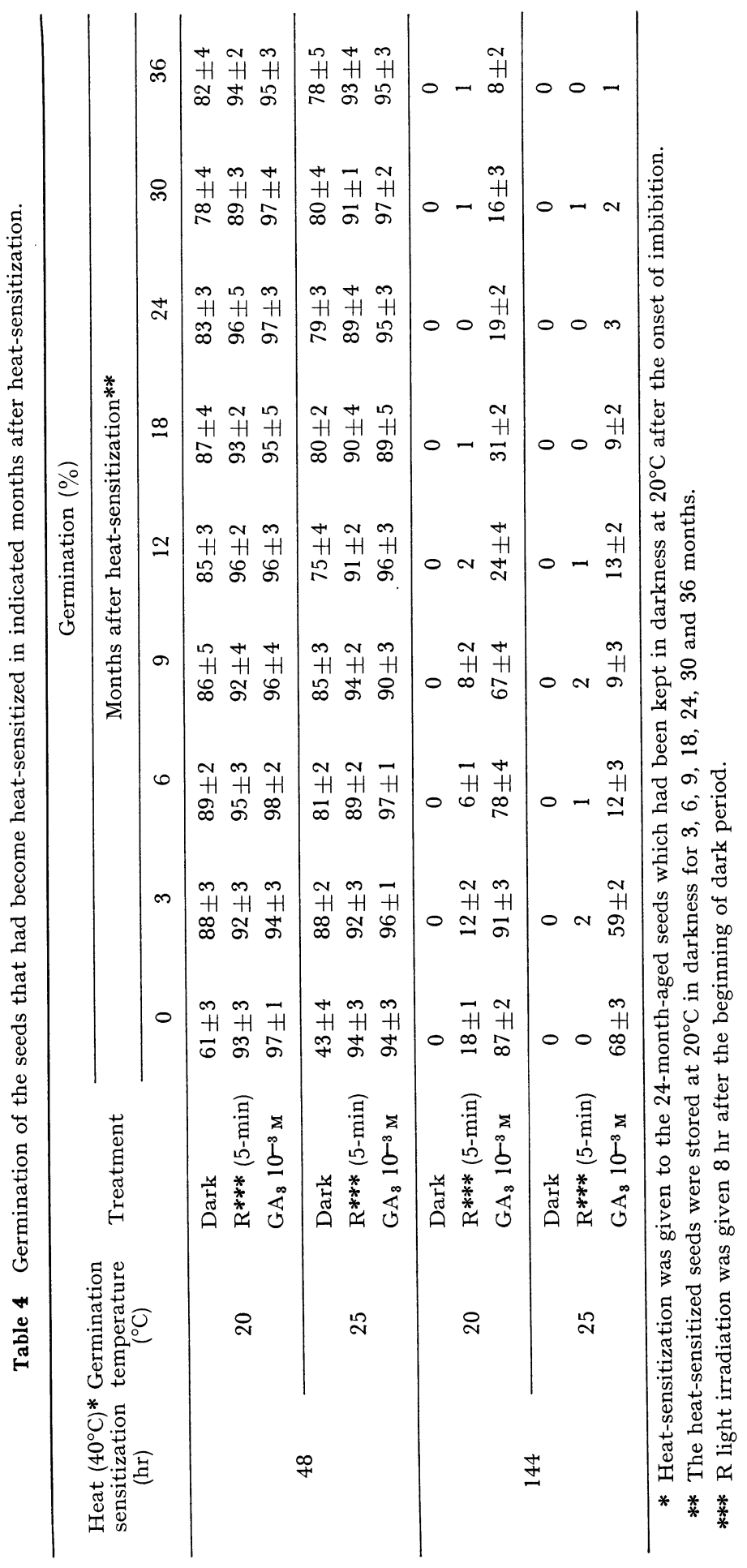


at $20^{\circ} \mathrm{C}$ not only in darkness or by 5 -min exposure to $\mathrm{R}$ light, but also by the application of $\mathrm{GA}_{3}$.

Germination in the seeds exposed to the prolonged and 144 FR light or heat-sensitized

The seeds exposed to the FR light for $48 \mathrm{hr}$ after the onset of imbibition germinated $72-97 \%$ respectively both at 20 and $25^{\circ} \mathrm{C}$ in darkness with $3,6,9,12,18,24$, 30 and 36 months following the exposure to FR light (Table 3 ) though the seeds have not exposure to $\mathrm{FR}$ light, did not germinate at all at $25^{\circ} \mathrm{C}$, and did not germinate more than $25 \%$ even at $20^{\circ} \mathrm{C}$ with 60 months after harvest (36 months after the exposure to FR light) (Table 1).

The heat-sensitized seeds kept at $40^{\circ} \mathrm{C}$ for 48 hr germinated $75-89 \%$ both at 20 and $25^{\circ} \mathrm{C}$ in darkness with $3,6,9,12,18,24,30$ and 36 months after heat-sensitization (Table 4). The heat-sensitized ones kept at $40^{\circ} \mathrm{C}$ for $144 \mathrm{hr}$, on the other hand, did not germinate at all or a little germinate both at 20 and $25^{\circ} \mathrm{C}$ in darkness. They, however, germinated 87 and $91 \%$ at $20^{\circ} \mathrm{C}$, and 59 and $68 \%$ at $25^{\circ} \mathrm{C}$ with 0 and 3 months after the heat-sensitization by the application of $\mathrm{GA}_{3}$, though they did not germinate more than $18 \%$ at $20^{\circ} \mathrm{C}$, and did not germinate at all at $25^{\circ} \mathrm{C}$ by 5 -min exposure to $\mathrm{R}$ light.

\section{DISCUSSION}

The response of seeds toward $\mathrm{R}$ and $\mathrm{FR}$ lights is influenced by the germination temperature ${ }^{2-5,9-14)}$ and other factors. ${ }^{4-12)}$

The rate of dark germination of Grand Rapids lettuce seeds was very high at $15^{\circ} \mathrm{C}$ with $0,6,12,36$ and 48 months after harvest, at $20^{\circ} \mathrm{C}$ with $6,12,36$ and 48 months, and at $25^{\circ} \mathrm{C}$ with 6,12 and 24 months. A brief (5-min) exposure to FR light has also very little influence on germination inhibition (Table 1). Their germination, however, decreased rapidly at $25^{\circ} \mathrm{C}$ with 48 months, and both 15 and $20^{\circ} \mathrm{C}$ with 60 months. Danielson and Toole ${ }^{13}$ ) reported that high temperature imposes a block upon germination beyond that of the active form of phytochrome. The germination of Grand Rapids lettuce seeds at $30^{\circ} \mathrm{C}$ is induced only by a prolonged exposure to $\mathrm{R}$ light more than $16 \mathrm{hr}$ in the fresh seeds and for $1-2 \mathrm{hr}$ in the aged (12 and 24 months) seeds. ${ }^{10)}$ The germination induction at $30^{\circ} \mathrm{C}$, therefore, may occur because the active form of phytochrome becomes functioning to induce germination or overcome blocks other than a direct inactivation of phytochrome system itself by a prolonged exposure to $\mathrm{R}$ light more than $16 \mathrm{hr}$ in the fresh seeds and more than 1-2 hr in the aged seeds which were in deteriorating stage.

$\mathrm{R}$ light requirement for germination induction in Grand Rapids lettuce seeds is more evident in the dormant and deteriorating stages than in the non-dormant stage if the germination temperature is the same, and is more evident at high temperature than at low temperature if the physiological stage of seeds is the same. FR light requirement for germination inhibition is more evident in the non-dormant stage than in the dormant and deteriorating stages if the germination temperature is the same, and is more evident at low temperature than at high temperature if the physiological stage of the seeds is the same. It is evident that the reversible photoreaction by $\mathrm{R}$ and FR lights is regulated not only by the temperature but also by the physiological state of seeds. Ikuma and Thimann ${ }^{3)}$ reported that low temperature stimulated lettuce seed germination at a point other than that controlled by phytochrome. Takeba and 
Matsubara ${ }^{14)}$ also explained that the germination of lettuce seeds is regulated not only by the phytochrome system but also by the thermo-labile factors. It is clear that the range of temperature and $\mathrm{R}$ light requirement for germination induction or the range of temperature and FR light requirement for germination inhibition changed with the physiological state of seeds. Grand Rapids lettuce seeds have been generally classified as the light-sensitive simply because their full germination occurs at 20 and $25^{\circ} \mathrm{C}$ in light, but they become light-insensitive by after-ripening and behave in a similar way to the classically light-insensitive Great Lakes, and become light-sensitive again in the deteriorating stage.

The germination induction and the sensitivity to $\mathrm{R}$ light and $\mathrm{GA}_{3}$ in the seeds exposed to FR light did not decrease with the passage of time after the prolonged exposure to FR light. Their germination rate showed a higher percentage than in the seeds which had not prolonged exposure to FR light with 60 months after seed harvest (36 months after the prolonged exposure to FR light) (Tables 1 and 3). It can therefore be said that the photoreversible induction or germination inhibition in the seeds exposed to FR light are due to the change from the non-dormant stage to the secondary photo-dormant stage. The photoreversible induction or germination inhibition in the heat-sensitized seeds, on the other hand, can be divided into two distinct physiological states. The germination induction and the sensitivity to $\mathrm{R}$ light and $\mathrm{GA}_{3}$ in the heat-sensitized seeds kept at $40^{\circ} \mathrm{C}$ for $48 \mathrm{hr}$ did not decrease with the passage of time after heat-sensitization. Their germination rate showed a high percentage both at 20 and $25^{\circ} \mathrm{C}$ as the same as that of the seeds exposure to FR light (Tables 3 and 4). It can therefore be said that the photoreversible induction or germination inhibition in the heat-sensitized seeds kept at $40^{\circ} \mathrm{C}$ for $48 \mathrm{hr}$ are due to the change from the non-dormant stage to the secondary thermo-dormant stage. The heat-sensitized seeds kept at $40^{\circ} \mathrm{C}$ for $144 \mathrm{hr}$, on the other hand, are led from the nondormant stage to the deteriorating stage caused by the thermal injury. This is because they did not show any germination both at 20 and $25^{\circ} \mathrm{C}$ in darkness with $0-36$ months after heat-sensitization (Table 4).

They also did not show more than $18 \%$ at $20^{\circ} \mathrm{C}$ and $2 \%$ at $25^{\circ} \mathrm{C}$ by 5 -min exposure to $\mathrm{R}$ light with $0-36$ months after heat-sensitization. They, however, germinated 87 and $91 \%$ at $20^{\circ} \mathrm{C}$, and 59 and $68 \%$ at $25^{\circ} \mathrm{C}$ by the application of $\mathrm{GA}_{3}$ with 0 and 3 months after heat-sensitization, though they did not germinate more than $8 \%$ with 36 months after it (60 months after seed harvest) (Table 4).

The seed dormancy means a state in which the germination is temporarily suspended under favorable and unfavorable temperature, or the cessation of growth in the embryo without losing and reducing its viability for prolonged time. ${ }^{15}$ ) Grand Rapids lettuce seeds in the deteriorating stage have decreased in tolerance to suboptimal temperature in germination and increased in sensitivity to R light, $\mathrm{GA}_{3}$ and thiourea. ${ }^{10)}$ With the further progress of deterioration, they decreased tolerance to optimal temperature and sensitivity to $\mathrm{R}$ light, $\mathrm{GA}_{3}$ and thiourea.

$\mathrm{R}$ light irradiation given to lettuce seeds increased the growth potential of the embryonic axes, and overcame the mechanical restraint imposed by the endosperm coat. ${ }^{4,16)}$ The increase in the growth potential of the embryo axes during imbibition has been shown to be closely related to the accumulation of free amino acids (especially Gln* and $\mathrm{Glu}^{* *}$ ) in the axes ${ }^{17)}$ and with the GS*** activity in the axes. ${ }^{18)}$ The

* Gln: Glutamine, ** Glu: Glutamic acid, *** GS: Glutamine synthetase. 
GS activity increased by the $\mathrm{R}$ light and $\mathrm{GA}_{3}$, but FR light given immediately after the $\mathrm{R}$ light cancelled the GS activity, and $\mathrm{R}$ light given immediately after the FR light increased again the GS activity. ${ }^{19)}$ It is reported further that the GS activity decreased rapidly during imbibition at $35^{\circ} \mathrm{C}$, but not at $18^{\circ} \mathrm{C}$. The germination inhibition in the lettuce seeds caused by the prolonged exposure to FR light or high temperature pretreatment at $40^{\circ} \mathrm{C}$ for $48 \mathrm{hr}$ after the onset of imbibition may inhibit temporarily the GS activity in their embryonic axes. The inhibition or decrease of their GS activity, however, may release or increase with the passage of time after heatsensitization, because they germinated $78-89 \%$ at $20^{\circ} \mathrm{C}$ and $75-88 \%$ at $25^{\circ} \mathrm{C}$ with $3-36$ months, though they did not germinate more than $61 \%$ at $20^{\circ} \mathrm{C}$ and $43 \%$ at $25^{\circ} \mathrm{C}$ with 0 month after heat-sensitization (Table 4).

The induction effects of germination in the heat-sensitized seeds kept at high temperature after the onset of imbibition are greater in $\mathrm{GA}_{3}$ than in $\mathrm{R}$ light, and at $20^{\circ} \mathrm{C}$ than at $25^{\circ} \mathrm{C}$ (Table 4). It may be considered that the seeds which are aged 24 months and heat-sensitized at $40^{\circ} \mathrm{C}$ for $144 \mathrm{hr}$ have two different germination pathways at least; the $\mathrm{R}$ light dependent pathway and the $\mathrm{GA}_{3}$ dependent one. The $\mathrm{R}$ light dependent pathway may be broken by heat-sensitization at $40^{\circ} \mathrm{C}$ for $144 \mathrm{hr}$, because they did not germinate at all or a little germinate both at 20 and $25^{\circ} \mathrm{C}$ (Fig. 3-B and Table 4). It may also be said that the two different germination pathways in the heat-sensitized seeds which are $\mathrm{R}$ light and $\mathrm{GA}_{3}$ dependent are due to the difference of the GS activity caused by $\mathrm{R}$ light and $\mathrm{GA}_{3}$, though the effects of $\mathrm{GA}_{3}$ on GS activity was very similar to that of $\mathrm{R}$ light. ${ }^{20)}$

The difference in germination induction by 5 -min exposure to $\mathrm{R}$ light or by the application of $\mathrm{GA}_{3}$ between the heat-sensitized seeds which were aged 24 months and those aged 36 and 48 months is due to the difference in the physiological state of seeds. It can be said that the seeds aged 36 and 48 months are in the initial phase of deteriorating stage, because the germination in the seeds aged 36 months began to decrease at $25^{\circ} \mathrm{C}$ in darkness even without heat-sensitization, though they showed high percentage germination at $20^{\circ} \mathrm{C}$ (Table 1 and Fig. 3).

Our findings may be summarized into the following scheme (Fig. 4) by adding to them a part of previous reports by Suzuki et al. ${ }^{9)}$ and Suzuki. ${ }^{10)}$

$A_{1}$ is the dormant stage without after-ripening, $A_{2}$ is the non-dormant stage which had become non photoreversible at 15,20 and $25^{\circ} \mathrm{C}$ by after-ripening, and $\mathrm{A}_{3}$ is the deteriorating stage which starts after the non-dormant stage which had become photoreversible again. $A_{1} \rightarrow A_{2}$ is the period of after-ripening, and it can also be called the dormancy releasing period. $\quad \mathrm{A}_{2} \rightarrow \mathrm{A}_{3}$ is the period proceeding to the deteriorating stage which is leading to the decrease in germination velocity and the loss of viability with the progress of ageing. With the further progress of ageing, they do not germinate by the exposure to $R$ light or $G_{3} . \quad A_{2} \rightarrow A_{3}$ stage should not be included in the period of after-ripening, because the period of after-ripening is referred to as a dormant or rest period. $\mathrm{A}_{2} \rightarrow \mathrm{A}_{2}{ }^{\prime}$ is changed to the secondary photo-dormant stage caused by the prolonged exposure to FR light. $\mathrm{A}_{2} \rightarrow \mathrm{A}_{2}{ }^{\prime \prime}$ is changed to the secondary thermo-dormant stage caused by heat-sensitization at $40^{\circ} \mathrm{C}$ for $48 \mathrm{hr}$, because the seeds in that stage do not lose or reduce its viability for a prolonged time, though their germination is temporarily suspended under favorable and unfavorable temperature. $\mathrm{A}_{2}$ $\rightarrow \mathrm{A}_{2}{ }^{\prime \prime \prime}$ is changed to the deteriorating stage caused by heat-sensitization at $40^{\circ} \mathrm{C}$ for 144 $\mathrm{hr}$, which leads to the decrease in germination velocity and the loss of viability by high temperature pretreatment after the onset of imbibition. 


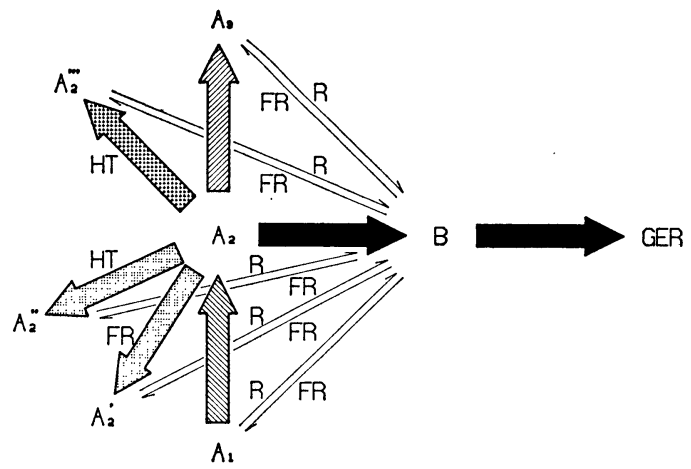

Fig. 4 A model of germination induction in the seeds of Grand Rapids lettuce. $A_{1}$, dormant stage; $A_{2}$, non-dormant stage; $A_{2}{ }^{\prime}$, secondary photodormant stage; $\mathrm{A}_{2}{ }^{\prime \prime}$, secondary thermo-dormant stage; $\mathrm{A}_{2}{ }^{\prime \prime \prime}$, deteriorating stage by high temperature pretreatment; $A_{3}$, deteriorating stage; $R$, red light; FR, far-red light; HT, high temperature pretreatment; B, precursors; GER, germination.

$\mathrm{A}_{1} \rightarrow \mathrm{B}, \mathrm{A}_{2}{ }^{\prime} \rightarrow \mathrm{B}, \mathrm{A}_{2}{ }^{\prime \prime} \rightarrow \mathrm{B}, \mathrm{A}_{2}{ }^{\prime \prime \prime} \rightarrow \mathrm{B}$ and $\mathrm{A}_{3} \rightarrow \mathrm{B}$ depend upon the active form of phytochrome or $\mathrm{GA}_{3}$ except at $30^{\circ} \mathrm{C}$. $\quad \mathrm{A}_{2}{ }^{\prime} \rightarrow \mathrm{B}$ and $\mathrm{A}_{2}{ }^{\prime \prime} \rightarrow \mathrm{B}$, furthermore, become independent of the active form of phytochrome or $\mathrm{GA}_{3}$ due to the releasing of secondary. photo- or thermo-dormancy.

To discuss the so-called high energy reaction by the prolonged exposure to FR light or the physiological nature in the dormant, secondary photo- or thermo-dormant and deteriorating seeds further detailed study will be required.

The author is very grateful to Dr. M. Konishi of Kyoto University, and Dr. Y. Oda and Dr. $\mathrm{N}$. Takahashi of Tohoku University for their critical reading of this manuscript.

\section{REFERENCES}

1) Borthwick, H. A., S. B. Hendricks, M. W. Parker, E. H. Toole, and V. K. Toole. 1952. A reversible photoreaction controlling seed germination. Proc. Nat. Sci. U.S.A. 38: 662-666.

2) Toole, E. H., V. K. Toole, and H. A. Borthwick. 1955. Interaction of temperature and light in germination of seeds. Plant Physiol. 3 : 473-478.

3) Inuma, H. and K. V. Thimann. 1964. Analysis of germination process of lettuce seed by means of temperature and anaerobiosis. Plant Physiol. 39: 756-767.

4) Scheibe, J. and A. Lang. 1965. Lettuce germination: Evidence for a reversible lightinduced increase in growth potential and for phytochrome mediation of the low temperature effect. Plant Physiol. 40: 485-492.

5) Scheibe, J. and A. LANG. 1969. Lettuce seed germination: effect of high temperature and repeated far-red treatment in relation to phytochrome. Photobiology 9: 145-150.

6) Koller, D. 1962. Preconditioning of germination in lettuce at time of fruit ripening. Am. J. Bot. 49: 841-844.

7) Снoi, K. S. and N. Takahashi. 1979. Studies on the lettuce seed germination with special to light response. Jpn. J. Breed. 29: 197-204.

8) Suzuki, Y. and N. TAkahashi. 1969. Red and far-red reversible photoreaction on seed germination of Cucumis sativus. Plant Cell Physiol. 10: 475-479. 
9) Suzuki, Y., Y. Soejima, and T. Matsur. 1980. Influence of after-ripening on phytochrome control of seed germination in two varieties of lettuce (Lactuca sativa L.). Plant Physiol. 66: 1200-1201.

10) Suzuki, Y. 1981. After-ripening as a factor in lettuce seed germination response. Am. J. Bot. 68: 859-863.

11) Evenari, M. and G. Neuman. 1952. The germination of lettuce seeds. 1. Light, temperature, and coumarin as germination factors. Palest. J. Bot. 5: 138-160.

12) Gutterman, Y., M. Evenari, and W. Heydecker. 1972. Phytochrome and temperature relation in Lactuca sativa L. Grand Rapids seed germination after thermodormancy. Nature New Biol. 235: 144-145.

13) Danielson, R. H. and V. K. Toole. 1976. Action of temperature and light on the control of seed germination in Alta Tall Fescue (Festuca arundiacea). Crop. Sci. 16: 317-320.

14) Takeba, G. and S. Matsubara. 1976. Analysis of temperature effect on the germination of New York lettuce seeds. Plant Cell Physiol. 17: 91-101.

15) Amen, D. L. 1968 . The model of seed dormancy. Bot. Rev. 34: 1-31.

16) Ikuma, H. and K. V. Thimann. 1963. The role of the seed-coats in germination of photosensitive lettuce seeds. Plant Cell Physiol. 4: 169-185.

17) ТАкева, G. 1980. Effects of temperature, red light and hormones on the accumulation of free amino acids in osmotically growth-inhibited embryonic axes of New York lettuce seeds. Plant Cell Physiol. 21 : 1645-1649.

18) TAKEBA, G. 1983. Phytochrome-mediated increase in glutamine synthetase activity in photosensitive New York lettuce seeds. Plant Cell Physiol. 24: 1477-1483.

19) TAкeBA, G. 1980. Phytochrome-mediated accumulation of free amino acids in embryonic axes of New York lettuce seeds. Plant Cell Physiol. 21: 1651-1656.

20) Takeba, G. and S. Matsubara. 1979. Measurement of growth potential of the embryo in New York lettuce seed under various combinations of temperature, red light and hormones. Plant Cell Physiol. 20 : 51-61.

\title{
〈和文抄録〉
}

\section{Grand Rapids レタス種子発芽の光および温度制御に及ぼす age の影望}

\author{
鈴木善弘 \\ 福島大学教育学部
}

Grand Rapids レタス種子の発芽に及ぼす赤色光 (red light), 遠赤色光 (far-red light) による光 可逆的反応は, 発芽温度のみならず age の進行によっておこる種子の生理的状態によって著しく異 なり，非休眠過程の種子よりも，休眠および発芽力消失過程の種子においてより明らかである。

遠赤色光 (far-red light) を長時間照射した種子，あるいは高温 $\left(40^{\circ} \mathrm{C}\right)$ で 48 時間処理した種子 は，照射しない種子あるいは高温処理を行わない種子より発牙速度の低下もおそく，発牙能力が長 く保持される.

光可逆性を失った非休眠種子の発牙に対する長時間の遠赤色光 (far-red light) 照射による光可逆 性の再誘導は光による二次休眠の誘導であるが，高温処理による光可逆性の再誘導は非休眠種子を 異なった二つの生理的状態へ誘導する. その一つは, 48 時間の高温 $\left(40^{\circ} \mathrm{C}\right)$ 処理による二次休眠の 誘導であり, 他の一つ以 144 時間の高温 $\left(40^{\circ} \mathrm{C}\right)$ 処理による発牙力の消失過程への誘導である.

高温処理によって誘導された発芽力消失の生理的状態にある種子の発牙に対する $\mathrm{GA}_{3}$ の効果は 赤色光 (red light) より大きい. 